DOI: 10.22559/folklor.901

folklor/edebiyat, cilt:25, sayı:98, 2019/2

\title{
Duvar Yazılarındaki Anlam Çeşitliliğine Tematik Yaklaşım (Muş Merkez Örneği)
}

\author{
A Thematic Approach to Meaning Diversity in Grafittis \\ (Muş/Merkez Sample)
}

\section{Rabia Şenay Şişman ${ }^{1}$}

Öz

Üslupları ve iletileriyle bir şekilde kent manzaralarına dâhil olmuş duvar yazıları yerel alt kültürlere ait görülmekte ise de öz itibariyle bir dil malzemesidir ve irdelenmesi gerekli göstergelerle donanmıştır. Bu itibarla bağlam-tümce çerçevesinde düşünülen araştırmanın çerçevesi Muş Merkez ilçesi sokaklarıyla sınırlandırılmış; graffiti kavramı içinde yerini almış metinlerin kapsadıkları kurgu ve dil ögeleri incelenmiştir. $\mathrm{Bu}$ amaç doğrultusunda türlü tepkilerin ifadesi olabilen tümcelerin işlenişinde içerdikleri anlamlar tematik açıdan sınıflandırılmıştır. Bu metinlerin anlam temelinde analizleri aracılığıyla dil beceri etkinlikleri için uygun olabilen aktif kullanım özelliklerine dikkat çekilmek istenmiştir.

Topluma has dikkatleri metinsel boyutta yansitan, popüler kent kültürü ögelerinden olan sokak/duvar yazılarının içerdiği çok yönlü ve bazen de komik olan anlamların, yaratıcılığı teşvik etme gücü kabul edilmektedir. Bu itibarla bu tarz tümcelerin ihtiva ettiği dil imkânlarının değerlendirilmesi, dil ile toplumun kesiştiği görsel araçların dile özgü dikkatlerle yapılandırılması öemsenmektedir. Varılan sonuçlarla Türk dili araştırmalarına; yaratıcı yazma alışkanlıklarının zevkli ve etkili kazanımına yerel ve tabii kaynaklı bir fayda sunulması hedeflenmiştir.

Anahtar sözcükler: Türk dili, dilbilimi, sokak/duvar yazıları, popüler kent kültürü, Muş-Merkez örneği

' Dr. Öğretim Üyesi. Muş Alparslan Üniversitesi Eğitim Fakültesi Türkçe ve Sosyal Bilimler Eğitimi Bölümü. rs.sisman@alparslan.edu.tr 


\begin{abstract}
Street/wall writings that are with their mode and messages found their ways into the city life considered as the notions that belong to local sub-cultures on the basis they are language materials and are surrounded by signs that need to be examined. By this way we limited our study to context-sentence frame within Muş-Merkez streets and the concept of graffiti is studied according to its language items. For this purpose sentences are taken into hand to analyze various meaning categories and the importance of these to the language skill activities are brought to attention.

The creative side of the multidirectional and -from time to time- funny grafittis that reflects the delicacies of the society as a form of text and that are the elements of urban pop culture are given importance while also classifying the sentences according to linguistics. The target of the text is to be beneficial to Turkish language researches, being a local and a natural source for the achievement of creative writing skills enjoyably and efficiently.
\end{abstract}

Keywords: Turkish language, linguistics, street/wall writings/grafittis, urban pop culture, Muşs sample

\title{
Giriș
}

Kamuya açı alanlardan olan sokaklar ve onların yüzleri olan duvarlar ihtiva ettikleri renkli çeşitlilikleriyle gündelik yaşamın resmi geçidi kabul edilebilirler. Grafiti kavramı içinde yazı, işaret/resim bir arada anılır ve her biri soyut ve somut anlamda kendilerine özgü bir yapı sergiler. Dil ve düşünce soyut ise onun aktarma aracı olan yazı/resim somuttur. Gözlemden soyut düşünceye, oradan pratiğe, nesnel bilmenin diyalektik yoluna ulaşılırken (Hançerlioğlu, 2010: 202) yazı/resim, özümsenmiş kişisel pratiklerin toplumsal plandaki paylaşımıdır denilebilir.

Bireyin mahremini, bu yüzeylerde yazı, resim gibi unsurlar yardımıyla paylaşmasının geçmişi, değişen boyut ve muhteviyatı insanlık tarihi kadar eskidir. Aralarında Dünya Mirası listesinde yer alan Altamira, El Castillove Tito Bustillo'nun da bulunduğu İspanya'daki 11 mağarada bulunan sembollerden olan ve üzerine boya üfleme ile yapıldığı belirlenen disk motifinin 40 bin 800 yıl önce yapıldığı yeni ve gelişmiş tarihlendirme tekniklerinin uygulanması sonrasında anlaşılmıştır. ${ }^{1}$

Graffiti etimolojik olarak 1851'de ortaya çıkarılan Antik Pompei Kenti'ndeki duvar yazıları için kullanılmış olup İtalyanca çizmek, karalamak anlamındadır ve 'graffito' kelimesinin çoğul hâlidir (Çakır, 2015: 9). Osmanlı'da hakkak adıyla bilinen ve taş, tahta gibi nesnelerin üzerine şekil/mühür kazan sanatçıların genellikle câmi avlularındaki sütun basamaklarında bulunan madenden yapılmış bilezikler üzerine yazdıkları "bilezik yazısı" denilen metinler, bir çeşit tarih kaydı kabul edilmekle birlikte kendi devirlerinin duvar yazısı örnekleri olarak görülebilir (Çakır, 2015: 45). 


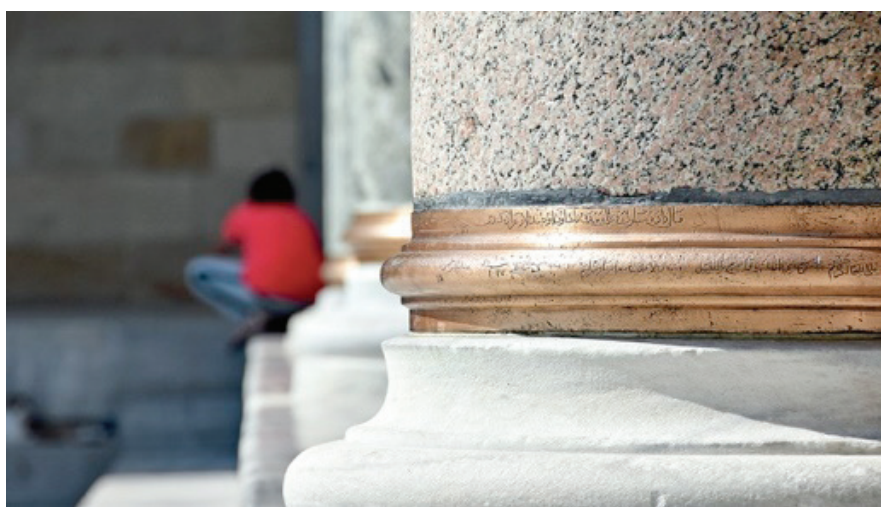

Resim 1. Kınalızade mübarek Zilkade'nin on üçünde Lazgırad'a gitti.

Sene 1041 (Miladi 1632-Lazgırad Silistre Sancağı́nda bir kasaba)

Kaynak:https://www.itohaber.com/haber/guncel (haber.com/haber/guncel/2018).

Almanya'nın ikiye bölünmesinin ardından 1961'de yükselen Berlin Duvarı protest tutumlu kimseler nezdinde çeşitli şekil ve slogan nitelikli sözlerin iletilmesi için uygun bir zemin olarak benimsenmiş ve bu amaç doğrultusunda kullanılmıştır. Duvarın belli amaçlar doğrultusunda kullanımı bir tür grafiti örneği olarak düşünülse de sosyal medyada 'tagging"² olarak bilinen ve 'Ben burdayım' diyebilme eylemi sayılan sokak yüzeylerinin kişisel anlamda tasarrufu, ilk defa 1970 New York'unda Yunan Demetrius'un kendi ifadesiyle can sıkıntısından dolayı duvara isminin kısaltması olan Taki ve adres numarası olan 183'ü yazmasıyla gündeme gelmiştir (Balkır ve Kuru, 2016: 1647).
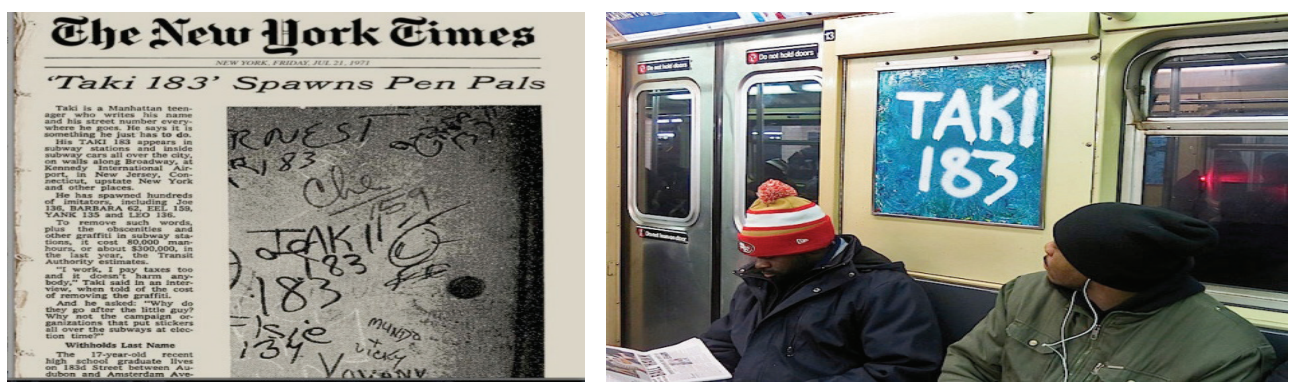

Resim 2. 21 Temmuz 1971 tarihli New York Times haberi'Taki $183^{\prime} \mathrm{Tag}^{3}$

Kaynak:http://www.woostercollective.com/post/new-york-times-1971-taki-183- (subway-art-graffiti, 2018).

Grafitinin Amerika kıtasını baştan başa çevreleyen yük trenleri aracılığıyla ülke toprakları içinde hızla yayıldığı varsayılır. Diğer yandan bu coğrafyada ötelenmiş insanlara ait rap müzik ya da break dans gibi kültürel unsurların protest tutumlu düşünüşlerle birleşmesi grafitinin gelişimine uygun sosyal ortamları hazırladığı bilinir. Style Wars ile Wild Style adlarıyla bilinen belgesellerde grafitinin yaratıcı ifade formu ve gelişimi 1980'li yılları kapsayacak şekilde işlenmiştir (Kuş, 2012). Bilhassa 1990'dan sonra Avrupa kıtasında tanınan bu protest 
tavır alış, sınırları yok sayan ileri teknoloji ürünü iletişim araçlarının sağladığı imkânların da etkisiyle küresel boyutta popüler hâle gelmiştir. Mesela işgal altındaki Batı Şeria'nın 1990'ların başındaki görüntüsünün en akılda kalıcı ayrıntılarından biri, kent duvarlarındaki kitlesel ayaklanmaya ilişkin yazılardır (Peteet, 1996: 139).

Günümüzde bu popüler ifade formunun icrası her ne kadar yasal çerçeveler içinde gerçekleştirilmeye çalışılsa da daha çok sokak sanatçıları tarafından yapılması ve kimi şartlarda kural ihlalini önemsemeyerek uygulanması ortaya çıkan ürünlerin sanat adı altında tescillenmesini güçleştirmektedir. Nitekim Glazer (1979) bir yazısında kural bozucu olarak vasıflandırdığı grafiti yazarlarıyla suç olgusu arasında doğrudan bir ilişki kurmaya çalışır ve grafiti ürünlerini sanatsal anlamda akademik ölçülerden uzak bulur.

Bazı çevrelerce sınır tanımaz bir sanat şeklinde yorumlanabilen duvar yazıları, olumsuz görüşlere rağmen toplumsal gelişmelerin izinde bunları yazanın amacına uygun içeriklerle zenginleşmiş ve hobi, şöhret elde etme, mesaj verme gibi kişiye özel eğilimlerle çeşitlenmiştir (Bilgiustam, 2015). Chalfant (1992) grafiti ürünlerini kent dilinin sergilendiği yerlerden sayar ve bu dilin tezahürüyle kent sokaklarının kişiselleştiğini ve bu kişiye özel kimliklerle farklı güzellikler kazandığını ileri sürer. Ayrıca grafiti yazarlarının genelde alt sınıfa dâhil kentli gençlerden kurulu olduğunu belirtir ve bunların kendi değerleriyle yeni bir sanat sistemi kurguladıklarını, bunu yaparken de yetişkinlere özgü değer ve sistemleri reddetmek istediklerini, belirtir. Bu ret Chalfant'a göre kamuya ait olma ile kişiye özel olma arasındaki sınırı belirleyen kontrol edici gücün sorgulanması anlamını da taşımaktadır.

Bugün çoğu ülkede kamu malına zarar verme kapsamında cezaî işlem gören graffiti uygulamasının yasa dışı tavsifi onun bir iletişim aracı olarak algılanmasının önüne geçememiştir. Mesela Borgomana (1982: 100; Aktaran: Emecan, 2007: 157) bu yazılar1 yazan kimsenin bizimle kurmak istediği bir iletişim ihtiyacının varlığından söz eder. Bu ihtiyaçtan olsa gerek sokakta doğmuş grafitinin eleştiri gücü ve kabiliyeti, katılımcıların protest tutumlarından ileri gelir. Nitekim protest düşünüşlü grafiti ustası Banksy "grafiti önemli ve geçerli bir sanat şeklidir. Eğer kapitalizmin ortaklığıyla yok edilseydi, bu bir utanç olurdu” (The Guardian, 2015) der. Dolayısıyla bu tarz çalışmaların kent duvarlarında duygu ve düşünceleri aktarabilme yeterliliği grafitinin sanatsal bir değer olarak kabulünü bugün için mümkün kılmış görülmektedir. Öyle ki Street Art denilen ve post grafiti olarak da tanımlanan Sokak Sanatı gibi yeni estetik yaklaşımların gelişimi, grafitinin akademik anlamda sanat sayılmayışından etkilenmemiştir. Yalnız icracılarına Writer, ustalarına da King, kadın icracılarına Bunny adı verilen pek çok stil ve çeşidi barındıran bu popüler ifade formunun kamu ya da kişi mülkiyetine zarar verme hâsıl olduğunda bazı hukukî yaptırımlarla sınırlandırılması hâlâ geçerlidir (Bilgiustam, 2015).

\section{Duvar yazılarındaki anlamsal çok yönlülük}

Moda/revaçta olanı yansıtması sebebiyle popüler kent kültürüne ait deyiş türü sözlerden sayılabilecek duvar yazıları, kamyon arkası yazıları gibi çoğu kez günlük dilde klişe hâle gelmiş, topluma mâl olmuş bazı söz/sloganlarla harmanlanmış tümcelerle kuruludur. Alg1 uyarımı açısından etkileyici olan bu üslup biçiminde bilinenler şaşırtıcı bir şekilde ters yüz edilir "susmak erdem olsa konuşmazdı duvarlar" tümcesindeki gibi. ${ }^{4}$ Bilinen, kanıksanmış gerçekler farklı bir bakışla sunulurken muhatabına bir yükümlülük getirdiğini söylemek de 
mümkündür. "Benim olan artık senin de kaderin" veya "sabret, şükret, seyret"5 örneklerindeki gibi. Tasarlanmış tümcedeki ima/örtülü anlamın etki gücünü popüler/moda kavramlardan alması bu yazılarda bulunan bir başka önemli dil kullanımıdır. "BİM'den daha ucuzsun"6 tümcesindeki gibi malum bir reklam vurgusunun kişisel amaçlı kurgusu bunun bir örneğidir.

Duvar yazılarındaki tümce kurgusundaki anlam, yadırganacak bir zıtlık taşıyorsa bu çoğu zaman okuyucuyu gülümsetme amaçlı kullanılmaktadır. Nash (1985: 34), “Gülmece tümcesinin kurgusundaki bazı ögeler, gülme olayının oluşacağına ilişkin bir işaret, bir yönelim, bir bağlam ve bir çelişki işlevi ve görevi yüklenirler" derken zıtlık unsurunun nükte yaratmaya yönelik rolünü ifade eder. "Evimiz kira olabilir ama semt bizimdir"7 tümcesindeki sahip olup/ olmama şeklindeki zıtlık nüktenin hazırlayıcısıdır. Belirli koşullarda, dünyadaki her türlü yapay veya doğal olgu, kendisiyle benzerlikler gösterebilen bir başka yapay veya doğal olguyu temsil etmekte kullanılabilir (Sperber ve Wilson 1986: 227). Dolayısıyla zıtlıklara dayalı çelişik ifadelerin tasarrufuyla beraber benzerlik ve imalardan yola çıkılarak düşüncelerin aktarılması söz gelimi; "bulutlar gider, sen gökyüzü"' gibi benzerlik kaynaklı bir anlatım ile veya "kaça kuruyoruz hayalleri, O’na mı" ile "ne hoş geldin öyle... can misın"10 tümcelerindeki gibi eğretileme veya mecaz-kinaye kaynaklı söz imkânlarından faydalanma tarzındaki dil kullanımları bu tür metinlerde sıç̧a gözlenebilen türdendir. Genel itibariyle ödünçleme anlam tarzında gerçekleşen bu kullanımlar ile metinlerdeki anlam çeşitliliğini doğuran çok yönlü anlam özelliği açığa çıkar. Özünlü, çok yönlü anlam taşıyan bu metinlerin bir türden başka bir türe kolaylıkla geçiş yapabildiğini dile getirir ve tema sınırlarını anlam ve amaç açısından belirlemenin güçlüğüne rağmen bu türleri tanım-yargı, manşet-açıklama, suçlama-yakınma, vecize-kalıp atasözleri, açıklamalı önermeler, değişen sözcüklü slogan sözler, ögütler, yanlış öncüller-kusurlu sonuçlar, metin ve eklentileri, mantık işlevli, haber işlevli olarak sıralar (Özünlü, 1991: 125).

\section{Graffiti ve taşıdığı dil imkânları}

“Graffiti esasen sözcük temellidir. Yazılı dilin varlığına dayalıdır.” (Phillips, 1999: 40). Çağdaş dilbilim görüşlerine göre en küçük metin birimi tümcedir. Tümcelerin bir araya getirilmesiyle daha büyük metinler oluşmaktadır. En küçük metin birimi olan tümcenin metinsel özelliğini bulup çıkarmak dilbilim alanının içindedir. Graffiti türü yazıların kurgu ve dil ögelerinin incelenmesi işte bu yüzden dilbilim alanına dayandırılmaktadır (Özünlü, 1991: 125). Bununla birlikte metinlerde ilk bakışta anlaşılan söylemin ardından sezilen çağrışımlar, benzetmeler ve ödünçlemeler ile bunlar için mahiyet bakımından türlü incelemelere münbit teşkil edecek dil imkânları taşındıkları söylenebilir. Söz gelimi bu tür bir görsel, dil eğitiminin genel ve özel amaçları doğrultusunda kontrollü bir şekilde olmak kaydıyla etkinlik başlı̆̆1 altında eğitim-öğretim materyalleri arasına dâhil edilebilir. Görsel ve bedensel uyaranlara sahip duvar yazıları "çevremizde görülen ve dokunulabilen her şey (Akpınar ve Aydın 2009: 105) demek olan gerçek nesneler” sınıfındaki dokümanlar arasında sayılabilir. Yalın'a (2009) göre gerçek eşyalar, öğrencilerde kalıcı öğrenme sağlamaktadırlar. Bu metinlerin ekseri gençler tarafından yazılıyor olmasından ötürü öğrencide haklı bir merak ve heyecan uyandırmanın yanı sıra ilgiyi de canlı tutacaktır (Karakaş ve Akın, 2018).

Raimes (1983), "bireysel deneyimle alakalı bir yazma eylemi gerçekleştiğinde öğrencilerin birbirleriyle paylaşımları olmaz" der, ama işlem, gösterilen bir resimle ilgili tekrar 
edildiğinde öğrencilerin deneyimlerini paylaşmalarının mümkün olduğunu belirtir. Resim gibi duvar yazısı da yararlanılabilir bir görseldir ve öğrenciler bu görsele dair duygu ve düşüncelerini birbirlerine aktif bir katılımla aktarma yoluna gidebilirler. Böylece sosyalleşme becerisini de kazanabilecek öğrenci bireysel anlamda dinamik ve iletişime açık olduğundan kendini anlatma gücünü artırma yollarını keşfedebilir (Özbay, 2013).

Gerçek hayata ait materyallerin kullanılması eğitim öğretim süreci içinde desteklenmektedir. 4-8 sınıf düzeylerinde kısa metin, resim, fotoğraf vb. görsel unsurların aktif kullanımının (MEB,2018: 12), öğrencilerin bu görsellerden faydalanarak çıkarımda bulunmaları aracılığıyla dil becerilerinin gelişimine katkı sağlayacağı düşünülmektedir. Bir başka açıdan duvar yazıları günlük hayata dair taşıdığı iletilerle görsel okuma, çıkarımda bulunabilme becerileri yanında öğrencilerin sosyal farkındalık gelişimlerine de faydalı olabilmektedir. Kaldı ki bu tip metinler kamusal alanların kullanılması ve kişi ile diğerleri arasında ortaklık oluşturması yönüyle sosyal boyutludur, çünkü duvar yazıları, doğaları gereği tepkiseldir bununla beraber tam da bu noktada yani, kendi ile öteki arasında ister istemez bir empatiyi gerekli kllar (Baker, 2015).

\section{Yöntem}

\subsection{Araştırmanın modeli}

Elde edilen görsel malzeme, mecazlar yoluyla nitel veri toplama çalışması temel alınarak yapılandırılmıştır. Mecazlar olguları bir alandan diğer bir alana taşır, gerçeği süzer ve basit bir şekilde tanımlar (Sterman, 1985; akt. Şimşek ve Yıldırım, 2016: 207). Bu itibarla mecazlar karmaşık değişkenlerin önemli özelliklerini basit bir formatta tanımlamakta oldukça etkilidirler (Morgan, 1980; akt. Şimşek ve Yıldırım, 2016: 207). Nitel araştırmalarda başvurulabilir olan görsel kaynaklar üzerinden gözlem ve doküman incelemesi gerçekleşmiş ve yazılar fotoğraflama ile kaydedilmiştir. "Fotoğraf gibi görsel malzemeler de nitel araştırmalarda kullanılabilir. Bu çeşit veri toplama yöntemi araştırmanın tekrar edilebilirliğini sağlamayı da mümkün kılar" (Yıldırım ve Şimşek, 2016: 190).

\section{2. Örneklem}

Muş’un Merkez ilçesinde bulunan İstasyon, Cumhuriyet caddeleriyle bu caddelere paralel bazı sokaklar küme örneklemesi için seçilmiştir. Bu sokaklar okul binalarının bulunması koşuluyla kümeye dâhil edilmiştir. "Örnekleme birimlerini eşit bir dağılımla belirlemeyi kolay kılan” (Kılıç, 2013) bu yöntemle 2018 yılı mayıs ayına ait duvar yazıları, ana iki cadde ve bu caddenin paralelinde bulunan okul binalarını çevreleyen sokaklar ${ }^{11}$ şeklinde kabul edilmiş küme içinden rastgele örnekleme ile tespit edilmiştir.

\subsection{Verilerin toplanması ve veri analizi}

Gözlem ve doküman analizi ile veri toplama işlemi gerçekleşmiştir. Verilerin toplanması örneklem kümesi üzerinden görsel kayıtlarla sağlanmıştır. Veri değerlendirilmesinde tematik çerçeve düzenlenmek istenmiş ve betimleme yoluyla tematik analiz yapılmıştır. Bu çalışma, yazılardaki duygu düşünce ayrımlarının kesin teşhisi güçtür. Bu itibarla öncelikle genel konu belirlemesi yapılmış ardından yazılar tema analizine göre sıralanmıştır. "Ne" sorusunun yanıtının karşılık bulduğu betimsel analizde bulguların açıklanması ve ilişkilendirilmesi daha 
belirgin yorumlamalarla mümkün olabilmektedir (Yıldırım ve Şimşek, 2016: 238). Dilbilim disiplini aracılı̆̆ıla inceleme amacı doğrultusunda verilerin anlama dayalı tasnifinde Özünlü’nün (1991:125) tespit ettiği kıstaslara yakın ölçütler esas alınmıştır.

\section{Bulgular}

Toplumdaki çeşitli kesimlerin dil kullanımlarını yansıtan, doğal ve güncel verilerle dolu olan duvar yazılarının incelendiği bu çalışma, Muş-Merkez sokakları ile sınırlandırılmış ve rastlantısal yöntemle belirlenmiş 138 tane metin ele alınmıştır.

\subsection{Genel konu ayrımı}

Metinlerdeki duygu-düşünce ayrımları kesin çizgilerle değil ancak genel itibariyle yapılmıştır. Buna göre tespit edilen konulara göre temel konu sıralaması şöyledir: Açıklama-yorum, suçlama-yakınma, talep, tanımlama, sevgi içerikli, espri içerikli, siyasi içerikli, küfür, isim paylaşımı.

Açıklama-yorum \%21,73 ve sevgi içerikli metinler \%21'lik paylarıyla duvar yazılarında karşılaşılan genel konuların başında yer almaktadır.

Her Derdi İçinize Atarsanız Ayağa Kalkamasınız... \# KimYaGer (Açıklama-Yorum)

Yükün dürüstlükse gücün belki düşer ama başın düşmez... \#Kimyager (Açıklama-yorum)

Bir Bakardım Eğilmiş Su İçiyor Gamzelerinden Kuşlar \# KimYaGer \& Alyehüs (Sevgi) gibi.

İsim paylaşımı ve küfür tarzındaki metinler \%1,44'lük pay ile en azı temsil etmiştir.

Seni sevmek zulümse koyam götüne (Küfür); \#APOŞ \#HAKO (İsim paylaşımı)

Bu sözlerin ayrıntılı tematik tasnifi aşağıda yer almaktadır ve burada sıralanan bazı duvar yazıları sadece büyük harf karakteriyle yazılmış olmasına karşın çalışmada örneklerin aktarılmasında küçük harf tercih edilmiştir. Yine de tümcede özellikle kullanılmış büyük harf varsa bu farklı yazım muhafaza edilmiştir. ${ }^{12}$

\subsection{Tema analizi ile gruplandırma/Tasnif etme}

$\mathrm{Bu}$ tür yazılarda en küçük metin birimi olan tümcelerin çok yönlü anlam ve amaç ihtiva etmeleri tematik analizin kesin çizgilerle belirlenememesi sonucunu ortaya çıkarmaktadır. Bununla birlikte incelenen metinlerin çözümlü tema gruplaması aşağıdaki başlıklar altında sıralanmaya çalışılmıştır.

\subsubsection{Tanımlama-Yargı Bildirme}

$\mathrm{Bu}$ tasnifte yazarın belirlediği eşitler arasında kurulmuş ilgi tanımlama şeklindedir. Hayat zorlanmaktır (Muho, 2018). ${ }^{13}$

Erkeklik öldürür

Benim olan artık senin kaderin

İnsan, zamanı durdurmak istediği yere aittir (Holmes, 2018).

Seni bekleyişimin adı yok, sadece yüreğimde lal olmuş duamsın (KimYaGer, 2018). 


\subsubsection{Başlık-Açıklama-Yorum}

Yazar bir yargıyı veya bir koşulu belirtirken kendince sebep ve öngörülerle de bu yargıyı açıklar. Açıklamanın yapılmayıp okuyucu anlayışına bırakıldığı örnekler de belirlenmiştir. Mesela "atların plakası olmaz" tümcesinde atın canlı olması plaka takılmamasının sebebi gibi görülse de esasen okuyucunun anlayışı özgür bırakılmak istenmiş gibidir.

Oksijeni bilmem ama kokun şart

Eskimek ne güzeldir eksilmedikçe (KimYaGer, 2018).

GS. candır, gerisi heyecandır (Eren, 2018)

Kapitali çözüm görenin sorun çözümüdür (Doktoraa, 2018)

Mademki dünya bir hiç, gece de iç gündüz de iç. (Jookerci, 2018)

Bu hayatta ya siyah ol ya beyaz; grisi yok bu işin (KimYaGer, 2018).

Muşluyuz mutluyuz (Eşşek, 2018)

Navigasyona gerek yok her şey yolunda (KimYaGer, 2018).

Yakalanmadığın sürece her şey yasaldır (KimYaGer, 2018)

Her sadakatin sonu ihanettir (F.A., 2018)

Önce hayaller ölür sonra insan (Gölge, 2018)

\subsubsection{Suçlama-Yakınma-İkaz}

Tümcenin başında bir yargı ve devamında da bu yargıyla çelişen sonuç/sonuçlar vardır. Mesela "götü kalksın diye değil kalbi atsın diye sevdik" tümcesinin başlangıcı küfürlü söz gibi olsa da aslında amaç bir yakınmadır.

Evimiz kira olabilir ama semt bizimdir, evvelallah (KimYaGer, 2018)

Dürüstlük pahalı mülktür ucuz insanlarda bulunmaz (Jookerci, 2018).

Gençler insan mıyız? Hayır insan olmak iyi değil.

İnsanlar sana kapıyı gösteriyor, sen hâlâ pencerelerine çiçekler koyuyorsun; YAPMA! (KimYaGer, 2018)

Sen bir nefessin içime çekiyorum mutlu oluyorum, sen Olma..

Böyle gece olmaz, getir ellerini (Firar, 2018)

Elimizde olmayan şeyler var, mesela elleri (Vefa, 2018)

Bana şiir yaz diyorsun iyi de sen kaç harf edersin... (Jookerci, 2018)

Çok yorgunum, kuş konsa kırılır dalım (KimYaGer, 2018).

\subsubsection{Vecize-Kalıplaşmış sözler, deyişler}

Farklı sözcüklerin kullanımıyla kalıplaşmış ifadelerin alışılmış hâllerinden sapmalar söz konusudur. Mesela "göz görmeyince gönül tiribe giriyor" tümcesinin bilinen hâli "gönül katlanır" iken "tiribe giriyor" denmesi beklenmedik bir hükümdür veya "bana kalırsa bana kal" tümcesindeki koşullu kullanım bir sözcük oyunu ile bitirilmiştir. Bahsi geçen çelişme noktası da işte bu dil sapmalarıdır.

Karanlığa küfredeceğine bir mum yak (darknes, 2018)

Gülü seven abisine katlanır (Şirinem, 2018).

Çok tatlısın ama şeker hastasıyım (KimYaGer, 2018). 
Kadın kadındır, çiçek babandır (DoktorAA, 2018).

Görünen köyü yaktım, kılavuzu elimde (darknes, 2018)

Ununa bir sözüm yok; eleğini astığın duvar yıkılsın! (KimYaGer 2018)

\subsection{5. İzahlı teklifler-Talepler}

Herhangi bir öneri açıklamasıyla birlikte ifade edilirken hâlihazır koşullara ilişkin eleştirilerin getirildiği görülebilir. Mesela "siyaha âşık iken maviyi sevemezsin" tümcesinde siyah kelimesi siyah renkli boya ile mavi kelimesi de mavi renkli boya ile yazılması görsel yollu açıklama şeklinde kabul edilebilir. "Er meydanında dansöz oynamaz" tümcesinde er meydanı mertlik sergilenen bir güreş yeri gibi düşünülmüş gibidir ve orada da ancak mertlik sergilenebilir. Dolayısıyla “mertlik kıvırmak ile olmaz” gibi bir çıkarım örtülü olarak sezilmektedir.

Yükün dürüstlükse gücün belki düşer ama başın düşmez (KimYaGer, 2018).

Her derdi içinize atarsanız ayağa kalkamazsınız... (KimYaGer, 2018).

Değer, değerse değer (Enes, 2018).

Kadın yaşamdır, kadını öldürmeyin (Soyib, 2018).

Umudumuz var da sabrımız kalmadı (KimYaGer, 2018).

Eksik kaldığında beni hatırla (KimYaGer, 2018).

S1kılırsan güneşten, gece oluruz erkenden (KimYaGer \& F.R.T.49, 2018).

Hayat işte, olur mu olur (KimYaGer,2018)

\subsubsection{Değișen sözcüklü slogan sözler}

Bilinen bir sözün bazı kelimelerinin değiştirilmesiyle üretilir. Mesela "nur içinde yatsın o güzel hayaller" tümcedeki temenni ifadesi aslında insan benzeri somut varlıklar içindir. Ama bu tümcede beklenilenin tersine, iyi niyet soyut bir duruma yöneliktir. "Hayat bazen çokmuş" metindeki /-mUş/ zaman ekinin maksatlı olarak büyük harfle yazılması ekin bilinen görevinin dışında kullanılmasına örnektir.

Beni çekemeyenler besmele çeksin de imana gelsin! (KimYaGer, 2018)

Yok mu bir mal, bana da desin "Recoşum gitme kal".

Prensler masallarda; efsaneler Muş’ta yaşar (KimYaGer, 2018)

Mutluluk lobim Abi..

\subsubsection{Tavsiyeler}

Yapılan tavsiye, gülmece amaçlı veya şaşırtmak içindir. Mesela "önce kendine gel, sonra meyhaneye" tümcesinde "kendine gelmek" yargısını tümcenin devamında, karmaşık ruh hâlinden çıkma olarak düşünmek mümkün iken yazar ifade kurgusunda ilgi çekmeyi planladığı bir tavsiyede bulunmaktadır.

Bir yerde tavuk döner varsa, umut vardır.

Hayatta adam olmak için adamlık bilmen gerek adamlık bilmiyorsan benden ders alman gerek.

Başını daima dik; tut unutma başı eğik olanın celladı çok olur (Jookerci, 2018). 


\subsubsection{Yanlış öncüller-Kusurlu sonuçlar}

Sunulan önerme sonrası ifadenin çelişki taşıması beklenirken bunun tam gerçekleşmediği örneklerdir. Mesela "beni öldüren her şey; beni yaşatır” tümcesinde öldürme ve yaşatma aynı kişi içindir. $\mathrm{Bu}$ ise ifadede beklenen çelişkiyi ortaya çıkarır.

Sokaklar sizin Muş bizim

\subsubsection{Metin ve eklentileri}

Bilinen bir söze veya slogan ve haber benzeri metinlere yapılan eklentilerle gerçekleşir. Adam gibi adam, Recep Tayyib Erdoğan.

Alayınız gelse alay ederiz

Deliye döner, geriye asla!

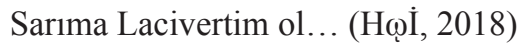

Siyahıma Beyaz ol....

\subsubsection{Haber işlevli sözler}

Malum bir yargı veya bilgiden faydalanılır. Bu bilginin kullanım amacı kişiye özgüdür.

Allah var, polis görmezse Allah görür (Örümcek, 2018)

Eksik olmayın, dedik; fazla olmaya başladınız. Hayırdır ?.. (Mamo,2018).

Pamuk Prenses de yakışıklı birini bulana kadar yedi cücelere ölü taklidi yapan bir kaşardı neticede (DoktorAA, 2018).

\subsubsection{Mantık işlevli sözler}

$\mathrm{Bu}$ sözler muhatabını gülümsetme belki de şaşırtma amacıyla mantığın kabul etmediği önermeler taşır. Aşağıdaki örnekler bu tür dil sapmalarının bulunduğu tümcelerdendir.

Kadın derin, adam yüzme bilmiyor (KimYaGer, 2018).

Seni de boş verdim boş verdiklerimin arasına hoş geldin ... (GÖLge, 2018)

Bizi de üzdüler; sabah kalkıp işe gittik (KimYaGer, 2018).

Bizi yakanlar terlemedi bile (KimYaGer, 2018).

Hayat davamız kısa, uzun kuşlar uçuyor (APOŞ, 2018).

Maviydi benim sevdam; yüreğime sığmadı gökyüzünü boyadı (DoktorAA, 2018).

Bir bakardım eğilmiş su içiyor gamzelerinden kuşlar (KimYaGer, 2018).

Eskiden mi güzeldi, eskiden mi güzeldik (KimYaGer \& USO, 2018)

Uzaktaydın sen, ama içimdesin (DoktorAA, 2018)

Dilin günlük konuşma üslubunda kullanılışına bağlı olarak farklı sesletim unsurlarının hâkim olduğu bu metinler yapısal olarak ölçünlü dilin kuralcı yaklaşımından uzaktır. Bu metinlerdeki dilin kullanımı hakkında alışılmıştan uzak anlatımlarla tümceleri kurgulama ve yazım kurallarından sapma şeklinde genel bir kanıya varılabilir. Bununla beraber farklı heyecan ve başkaca düşünüşlerin vurgulandığı duvar yazılarındaki sözlerin alışkanlıkları tersine çeviren dizilimlerini ve maksatlı açılımlarını, dilin zihinle kurduğu ilişkinin estetik sonuçları gibi yorumlamak mümkündür 


\section{Tartışma, sonuç ve öneriler}

Dil ve toplum birbirinden ayrı düşünülemez. Popüler kültür unsurlarıyla birlikte yerel ağız özelliklerinin görüldüğü duvar yazıları günlük dil ile toplumun kesiştiği görsel araçlardandır. Bilhassa gençler arasında toplumsal planda revaçta olan bu iletişim metodu hızlı ve değişkendir. Düne ait paylaşımlar bugün değişebilmekte hatta karalama benzeri üstü çizilerek duvarlarda yeni iletilere yer açılmaktadır. Hızlı akış içinde önceden bilinen veya duyulan bilgiler, yeni tümce kalıplarında okurlarını bu eski yüzeylerde fazla bekleme yapmaksızın karşılamaktadır. Dolayısıyla zengin ve devingen söz dizimi örneklerine sahip duvar yazıları, yaratıcılığını hayatın içinden alan çarpıcı paylaşımları ile esprili ve çoğunlukla şaşırtan içerikleriyle geçerliliklerini kaybetmeye uzak görünmektedirler. Bu yüzden kamu yasalarının tahdidine rağmen sokak yüzeyleri hâlâ muhatabının duygu ve düşünce dünyasını uyaran etkili ifade biçimlerinin üretildiği mahaller arasında yer almaktadır.

"Yaşam amacım, mutluluğu anlatanla değil yaşatanla ilgileniyorum"14 veya "artık bazı yolların dönüşü bazı hataların özrü bazı insanların ne imkânı nede anlamı var"15 örneklerindeki gibi dil kullanım becerisi hem yazarların eğitim düzeyleri ve içtenlik dereceleriyle yakından ilgilidir hem de onların anlık duygu değişimlerinden sayılabilecek ihmal etme, önemsiz sayma, kararsız kalma gibi farklı tutumlarıyla sıkı ilişkilidir. Bununla birlikte "İşlenen tüm suçlar üstüne kalcak", "Kimyager Emmi çay verem mi” örneklerindeki gibi konuşma üslubu özelliği neredeyse hemen her metinde tanık olunan bir durumdur. Bu tip tümceler arasında bireye dönük veya toplumun hedef alındığı anlatımların bulunduğu örnekler çoktur: "Amca kaçırdık mı hayatı?”; "Sevgili günlük ben kaybettim”; "Hayat buysa üstü kalsın” gibi örnekler bireye dönük olanlardandır. Çöp dökülmüş bir duvar dibinin hemen üstünde yazılı olan "burası neden böle temiz?" tarzında kinayeli bir sorgulama ile bir evin ön cephesine yazılmış "evin yok mu senin, sür arabanı" şeklinde ikaz mahiyetinde emretme, konuşma formunun topluma dönük kurgulandığı tümcelerdendir.

Sözlü ifade becerilerinin yazıya geçmiş hâli denilebilecek bu metinler, tümce ve tümce yapısını oluşturan bileşenlerin kavranmasında faydalı olabilecek donanımlara sahiptirler. Bunlar siralanacak olursa:

a. Metinlerin konuşma diline yakın ses bilgisel ve sesletimsel özellikleri sayesinde sözlü dilin gelişim izlerinin bu yazılarda takip edilebilir olmasının yanında anlamsal boyutta tümcelerin çok yönlülükleri onları ayrıca önemli kılmaktadır.

b. Metinlerde tutulan yolun çoğu kez dilin kuralcılığından uzak, ekseri yanlış olarak yorumlanabilecek sözlü ifade unsurlarıyla kurulu oluşu eksik/kusurlu kullanım konusunda öğreticiye malzeme çeşitliliği sunar.

c. Başkalarının dil yanlışlarını ararken sözlük, yazım kılavuzu gibi kaynaklara müracaat etme, sıkça olması koşuluyla ölçünlü dilin kurallarını öğrenmede öğrenci açısından pekiştirici olabilir. Üstelik metinlerin öğrencilerin yaşlarına yakın veya kendilerine yaşıt kimselerce yazılıp çizilmesi ister istemez bir merakı uyandırabilir hatta dil ve yazım yanlışlarını belirleme sürecini zevkli bir öğrenme faaliyetine dönüştürebilir.

d. Çoğu yazıların internet gibi ortak mecralardan etkilenilerek oluşturulması metin içeriğindeki kelimelere aşinalık sonucunu ortaya çıkarır. Yazılarda gözlemlenen "alayınız gelse, alay ederiz"; "kızım kırdığın bu kalp ananın porselen takımı değil” tarzındaki bir kısım ano- 
nim anlatımların sebebi de bu olsa gerektir. Dolaylı da olsa bilinen bu metinlerin henüz yeni deneyimlenecek uygulamalar için kullanılması ders konusuna olan dikkati artıracak ve derse aktif katılımı sağlanabilecektir.

e. Yazıların okul duvarları içinde olmayıp dışardaki hayatla kuşatılmış çevrede bulunmas1 eğlenceli performans çalışmalarına elverişlilik olarak düşünülebilir.

f. Yaşayan, canlı, etkin dili yansıtan ve temel-mecaz anlam ile yan anlam gibi çok yönlü anlamları bünyesinde barındıran duvar yazıları, dil eğitimi-öğretimi programlarının geliştirilmesi adına çeşitli veriler sunma yeterliliğinde olmakla birlikte yazılardaki çok yönlü anlamlılık, metinlerin anlamsal bütünlüğünü kavramada bir zorluk sayılabilir. Halbuki bu zorluk söz dağarcığının gelişimi üzerine olumlu sonuçlar doğurabilir. Çünkü kelimenin yeni anlamlarını, metnin içinden keşif ile gerçekleşecek analiz-sentezin, zihinde yapılandırılma süreci, dil ile ilgili becerilerin gelişimine hizmet edebilir. Öğrencilerin yeni kelimeler öğrenmeleri ve bunların farklı anlamlarını kavramaya çalışmaları, okuduğunu anlamayı kolaylaştırabilecektir. Hiç şüphesiz okuduğunu, gördüğünü, dinlediğini anlayarak kelimelerin gücünü kavramış öğrencilerin yetişmesi eğitim-öğretim politikalarının önemsenmiş amaçlarındandır.

g. Dil öğretiminde amaçlanan basamaklardan biri de duygu düşünce dünyasının gelişimidir. Bir bakıma bu gelişimi destekleyebilecek dolaylı anlatımın ustalıkla kullanıldığı bu dokümanlara erişim öğretici için olduğu kadar öğrenci için de en az çaba iledir. Üstelik bunların gerekirse sınıf ortamına taşınması ve akıllı tahtalarda yansıtılması günümüzdeki akıllı telefonların çeşitli teknik özellikleri sebebiyle problemsiz olabilmektedir.

Görülüyor ki duvar yazıları taşıdığı toplumsal-dilsel içeriklerle pek çok sosyal disipline veri sunabilecek çeşitliliktedir. İletişim aracı olan yazının çoğu zaman sosyal kimliklerle kent duvarlarında açığa çıkması, bu ürünlerdeki dil kullanımlarını farklı kılan ayrıcalıkların incelenmesini gerekli hâle getirmiştir. Bu çalışmanın amacı da metinlerin analiziyle temasal gruplamanın tanzimi ve sonrasında yine bu metinlerin eğitim-öğretim hedefleri doğrultusunda faydalanabilir etkin nitelikli materyaller olduğuna dikkat çekmektir.

\footnotetext{
Notlar

1 (bbc.com/turkce/haberler, 2018)

2 Kullanılan nickname'i (imzayı) duvarlara sprey, marker vb. araçlarla yazmak.; tagging: Etiketleme.

3 2. dipnota bk.

4 Mizah Ürünü 20 Duvar Yazısı

5 Muş-Merkez sokakları.

6 http://www.baglandirek.com/

7 Muş-Merkez sokakları.

8 Muş-Merkez sokakları

9 Muş-Merkez sokakları.

10 Muş-Merkez sokakları.

11 Muş Telekom Ortaokulu ile Vali Adil Yazar İlköğretim Okulu

12 Metinlerin tamamını burada vermek makale sınırlarını zorlayacağından sadece yüzdelik payları en yukarda ve en aşağıda olanları "Ekler" bölümünde yazma tercih edilmiştir. Makale sonunda yazılarının bulunduğu fotoğrafların ancak bir kısmına yer verilmiştir.

13 Parantez içi ibareler metni yazanın belirttiği şekildedir. Yazarın belli olmadığı durumlarda ise yazar kısmı boș bırakılmıştır.

14 "Yaşam amacim, mutluluğu anlatanla değil yaşatanla ilgilenmektir" biçimindeki düzeltme, tümcedeki maksadı daha anlaşılır kılacaktır.

15 “Artık ne bazı yolların dönüşü ne de bazı hataların özrü var; bazı insanların ise artık ne imkânı ne de anlamı var” biçimindeki düzeltme, tümcedeki maksadı daha anlaşılır kılacaktır.
} 


\section{Kaynaklar}

Akpınar, B. ve Aydın, K. (2009). Çok duyulu (multisensory) yabancı dil öğretimi. Tubav Bilim Dergisi 2 (1): 105-112.

Baker, M. (2015). Translating dissent: voices from and wit the Egyptian revolution. Routledge.

Balkır, N. ve Kuru, A.Ş. (2016). Sokak sanatı ve graffitinin pedagojik bir yöntem olarak işlerliği. İdil, 5 (26), s.1645-1658.

Borgomana, L. (1982). Et vous? Lecture de graffiti dans la rue?, Français dans le Monde. No. 173, Paris, 94-103.

Çakır, M. S. (2015). Türkiye'de graffiti ve sokak sanatı. T.C. Yeditepe Üniversitesi Sosyal Bilimler Enstitüsü Plastik Sanatlar Bölümü. Yayımlanmamış Yüksek Lisans Tezi. İstanbul

Chalfant H. (1992). "No one is in control" s.3-13 Vandalism: Research, Prevention and Social Policy (https://www.fs.fed.us/pnw/pubs/pnw_gtr293.pdf)

Emecan, N. (2007). Duvar yazıları ne diyor? s. 157-168. Journal of Turkish Linguistics. Volume 1, Number 1.

Glazer, N. (1979). "On subway graffiti in New York" s. 3-11 National Affairs, The Public Interest (https://www.nationalaffairs.com/public_interest/detail/on-subway-graffiti-in-new-york)

Hançerlioğlu, O. (2010). Düşünce tarihi. İstanbul: Remzi

Karakaş, R. \& Akın, E. (2018). Yazım kuralları öğretiminde duvar yazılarından yararlanma. Anemon Muş Alparslan Üniversitesi Sosyal Bilimler Dergisi. Cilt. 6, Sayı. 5, sayfa. 647-654. DOI:10.18506/ anemon.379413

Kılıç, S. (2013). Örnekleme yöntemleri. Journal of Mood Disorders. Volume. 3, Number. 1./www. jmood.org.

Morgan, G. (1980). Paradigms, metaphors and puzzle solving in organization theory. Administrative Science Quarterly. 25, 605-622.

Nash, W. (1985). The language of humour, London: Longman.

Özbay, M. (2013). Özel ögretim yöntemleri 1. Ankara: Öncü Kitap.

Özünlü, Ü. (1991). Türk gülmecesi’nde duvar ve kaldırım yazıları. Dilbilim Araştırmaları Dergisi. Cilt. 2, sayfa.122-132.

Peteet, J. (1996). The writing on the walls: The graffiti of the Intifada. Cultural Anthropology. https:// doi.org/10.1525/can.1996.11.2.02a00010.

Phillips, S. A. (1999). Walbangin' grafiti \& Gangs in L.A., Chicago \& London: The University of Chicago.

Raimes A. (1983). Techniques inteching writing. New York: Oxford Unıversity Sterman, J. D. (1985). The growth of knowledge: Testing a theory of scientific revolutions with a formal model. Technological Forecasting and Social Change. 28, 93-122.

Sperber, D. ve Wilson, D. (1986). Relevance: Communication and cognition. Oxford: Blackwell.

Yalın, H. İ. (2009). Yabancı dil ögrenme yolları. İstanbul: Alfa .

Yıldırım, A. ve Şimşek, H. (2016). Sosyal bilimlerde nitel araştırma yöntemleri. 10. Baskı, Ankara: Seçkin. 


\section{Elektronik kaynaklar}

http://www.baglandirek.com/gercek-mizahin-sokakta-oldugunu-gosteren-duvar-yazilari.html (erişim: 10.09.2018)

https://www.bbc.com/turkce/haberler/2012/06/120615_reddot_cave (erişim: 09.09.2018)

https://www.bilgiustam.com/graffiti-nedir-nasil-ogrenilir-tarihcesi-turleri-nelerdir/(erişim: 26.01.2019) https://www.theguardian.com/cities/2015/jan/07/urban-graffiti-force-good-evil (erişim: 27.01.2019) https://www.itohaber.com/haber/guncel/208560/osmanli_nin_duvar_gunlukleri_bilezik_yazilari.html Mizah Ürünü 20 Duvar Yazıs1 - Ofpof.com http://mufredat.meb.gov.tr/Dosyalar/201812312239736T\%C3\%BCrk\%C3\%A7e $\% 20 \% \mathrm{C} 3 \% 96 \% \mathrm{C} 4 \% 9$

Fretim\%20Program\%C4\%B1\%202018.pdf (erişim: 10. 11. 218)

http://ofpof.com/keyif/mizah-urunu-20-duvar-yazisi/2 (erişim: 10.09.2018)

https://www.routledge.com/Translating-Dissent-Voices-From-and-With-the-Egyptian-Revolution/

Baker/p/book/9781138929876 (erişim: 09.09.2018)

http://streetartnyc.org/wp-content/uploads/2015/06/taki183-subway-art-graffiti.jpg(erişim: 11.09.2018)

http://www.woostercollective.com/post/new-york-yimes-1971-taki-183-spans-penpals(erişim:11.09.2018)

Kuş, O. (2012). https://www.dadatart.com/2012/01/01/graffiti-nedir-graffiti-tarihi (erişim: 25.01.2019)

\section{Ekler}

1. Beni seviyormusun? A.) Evet B.) Eŕe C.) neam D.) Yes \# Vefa (Sevgi)

2. Bir Bakardım Eğilmiş Su İçiyor Gamzelerinden Kuşlar \# KimYaGer \& Alyehüs (Sevgi)

3. Böyle gece olmaz ஸ̀ Getir Ellerini \# Firar (Sevgi)

4. Bu şehrin delisiyim (Sevgi)

5. Bulutlar gider, sen gökyüzü (Sevgi)

6. Çok TaTlısın Ama Şeker hasTasıyım \# KimYaGer (Sevgi)

7. Eksik kaldığında Beni hatırla \# KimYaGer (Sevgi)

8. Elimizde olmayan şeyler var Mesela elleri \# Vefa (Sevgi)

9. Gökyüzünde yıldız çok Ay bir tane dünyada İnsan çok Sen bir tane (Sevgi)

10. GönLüm Hep Seni arıyor neredesin sen YASINN (Sevgi)

11. GS. Candır. gerisi heyecandır \# EREN (Sevgi)

12. Gülü SeveN AbisiNe KatlaNır \#7 seNeciK (ŞİRINEM) (Sevgi)

13. Maviydi benim Sevdam Yüreğime Sığmadı Gökyüzünü Boyadı \# DoktorAA (Sevgi)

14. NE hoş geldin öyle CAN misın FURKANAYŞE (Sevgi)

15. Neredesin BAL (Sevgi)

16. Oksijeni Bilmem Ama Kokun Şart (Sevgi)

17. One Love Başkan (Sevgi)

18. Pamuk Şekerli hayallerimiz vardı sen gittin yarım kaldı.. \#KimYaGer (Sevgi)

19. Sana yolculuklar yapmak istiyorum 'CAN' kenarı olsun Cemal Süreya (Sevgi)

20. Sarıma Lacivertim ol... Hஸ் (Sevgi)

21. Sen benim YILDIZ YILDIZ (Sevgi)

22. Sen bir nefessin içime çekiyorum mutlu oluyorum sen olma..(Sevgi)

23. "Seni bekleyişimin Adı yok sadece yüreğimde lal olmuş duamsın" \# KimYaGer (Sevgi) 
24. Tüm çiçekler bir olsa senin gibi kokmaz \# KimYaGer (Sevgi)

25. Yok mu bir mal, bana da desin "Recoşum gitme kal (Sevgi)

26. SIYAHıma BEYAZ ol... (Sevgi)

27. TÜRKIYY evimiz ERDOĞAN Babamız (Sevgi?)

28. Bana şiir yaz diyorsun iyi de sen kaç harf edersin...\#Jookerci (Sevgi?)

29. Uzaktaydın Sen, Ama İçimdesin \#DoktorAA (Sevgi)

30. ALLAH var Kimyager Polis görmezse ALLAH görüyor \# Örümcek (Açıklama-Yorum)

31. Atların plakası olmaz (Açıklama-Yorum)

32. Artık bazı Yolların dönüşü Bazı hataların özrü Bazı insanların ne imkanı nede anlamı var.. \#KimYaGer (Açıklama-Yorum)

33. Babalar Halden Anlamaz!...Kudüs Müslümanlarındır \# USO \& Z.E (Açıklama-Yorum)

34. Ben kaybettiğimi özlerim vazgeçtigimi Değil...! \# KimYaGer (Açılama-Yorum)

35. Beni öldüren her şey; beni yaşatır (Açıklama-Yorum)

36. Benim olan artık senin de Kaderin (Açıklama-Yorum)

37. Bir kere İhanete uğradın mı yeğen Anılar sana bataklık olur yeğen hatırladıkça çekerler seni içeri hatırladıkça affetmek istersin yeğen \#DOKTORAA (Açıklama-Yorum)

38. Bu Hayatta iki şeye Güvenirim Bir aynaya Baktığımda Gördüğüme: İki Gökyüzüne Baktığımda Göremedim \#Filozof (Açıklama-Yorum)

39. Bütün Yollarımız Geçerdi Gül Bahçelerinden ne Güzel zamanlar vardı Eskiden ... \#KIMMYAGER (Açılklama-Yorum)

40. Dürüstlük Pahalı Mülktür Ucuz İnsanlarda Bulunmaz \#Jookerci (Açıklama-Yorum)

41. Eskiden mi guzeldi, eskiden mi güzeldik \# KimYaGer \& USO (Açıklama-Yorum)

42. Eskimek Ne Güzeldir Eksilmedikçe \# KimYaGer (Açıklama-Yorum)

43. Gençler insan mıyız? BòM Diiliz Hayır insan olmak iyi değil. (Açıklama-Yorum)

44. Hayat işte oLurmu oLur...... \#Kimyager (Açıklama-Yorum)

45. Hayata Adam olmaK için Adamlık bilmen gereK Adamlık bilmiyorsan benden ders Alman gerek. (Açıklama-Yorum)

46. Her Derdi İçinize Atarsanız Ayağa Kalkamasınız... \# KimYaGer (Açıklama-Yorum)

47. Herkes her şeyin farkında ve Kimse Hiçbir şeyi Yanlışlıkla Yapmadı ...! \# KimYaGer (AçıklamaYorum)

48. Herkes kendi tarzında şizofren ... \# KimYaGer (Açıklama-Yorum)

49. Herkesten Bir Anı Saklar Bu Yollar... \# KimYaGer...(Açıklama-Yorum)

50. Kadın derin Adam Yüzme bilmiyor \# KIMYAGER (Açıklama-Yorum)

51. Kapitali çözüm görenin sorunu çözümüdür... \#DoktorAA (Açıklama-Yorum)

52. Önce hayeler ölür sonra insan \# Gölge (Açıklama-Yorum)

53. Pamuk Prenseste Yakışıklı birini Bulana kadar 7 cücelere ölü taklidi Yapan bir kaşardı Neticede \# Doktor AA (Açıklama-Yorum)

54. PrensLer MasaLLarda EfsaneLer MUŞ’TA YAŞAR \# KimYaGer (Açıklama-Yorum)

55. Sabret Şükret Seyret \# KimYaGer (Açıklama-Yorum)

56. Siyaha aşık iken maviyi seveemezsin (Açılama-Yorum)

57. Şu an zaman dursun istiyorum, Çünkü insan, zamanı durdurmak istediği yere aittir... Holmes (Açıklama-Yorum)

58. Yaşama amacım Mutlulugu Anlatanla Degil YAŞATANLA ilgileniyorum (Açıklama-Yorum) 
59. Yükün dürüstlükse gücün belki düşer ama başın düşmez... \#Kimyager (açıklama-yorum)

60. Giren acımaz şemsiye (Küfür) (Metnin bir kısmı koyu bir boya ile kapatılması sebebiyle okunamamıştır).

61. Seni sevmek zulümse koyam göt (Küfür) (Yazı üstüne başka bir söz yazılması sebebiyle metnin bir kısmı okunamamıştır).

62. \#APOŞ \#HAKO (İsim paylaşım1)

63. İshak Adem Sükür Nurulah Alan Ömer Engo Hamdo Ömerik Us ... \#murder\# (İsim paylaşımı)

II. Merkez/ Muş (Cumhuriyet ve İstasyon Caddeleri; Muş Telekom Ortaokulu ile Vali Adil Yazar İlköğretim Okulu binalarının yakın çevresi, [resimlerden birinde görülen sokak adı levhasında yazılı Sunay Mahallesi Cumhuriyet Caddesi'ndedir ve Muş Telekom Ortaokulu'nun yakın çevresinde bulunmaktadır] gruba dahil edilmiş tek örnek: Yeni Cezaevi Caddesi- Saray Mahallesi

\section{ÖRNEKLER}
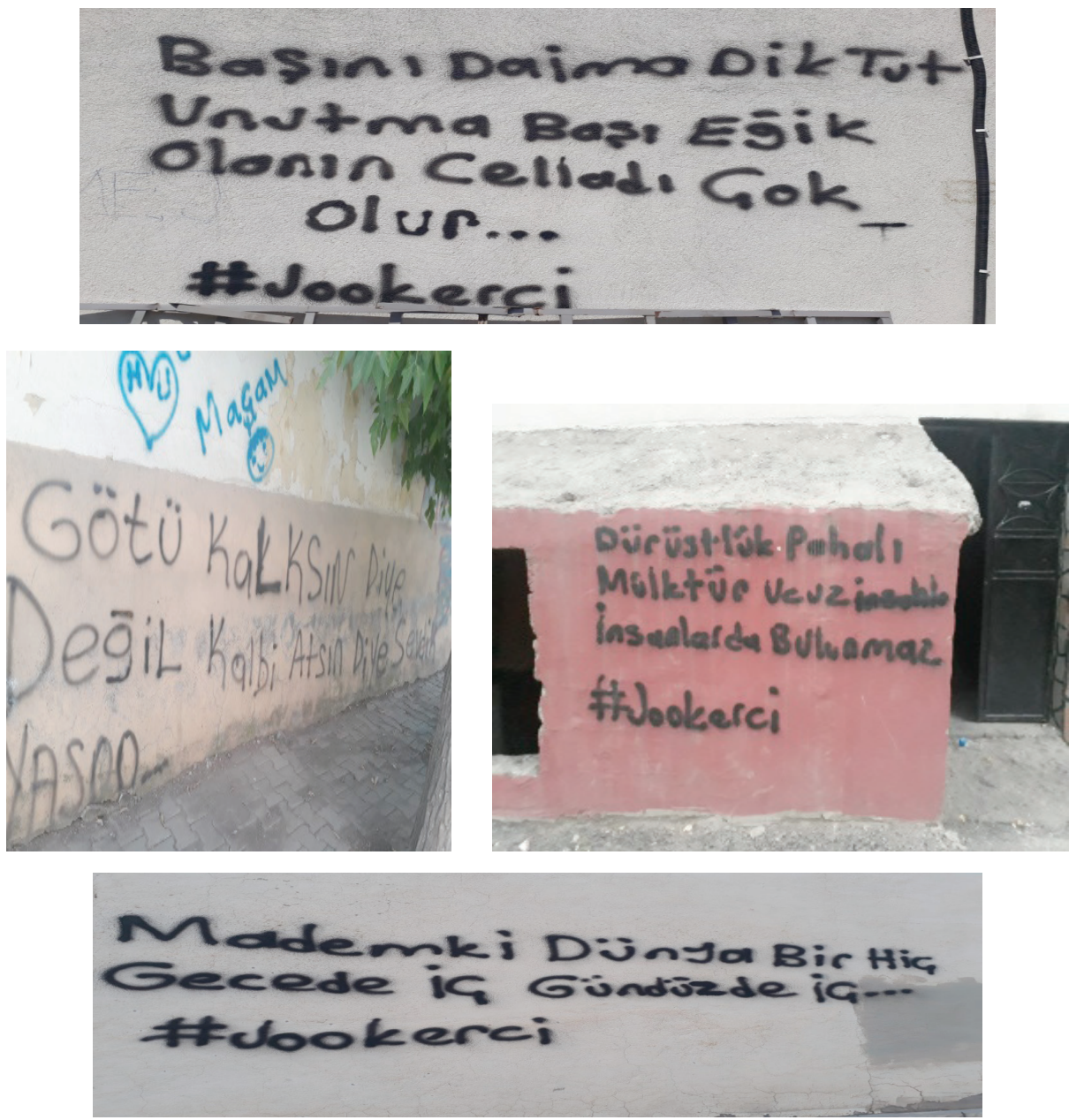

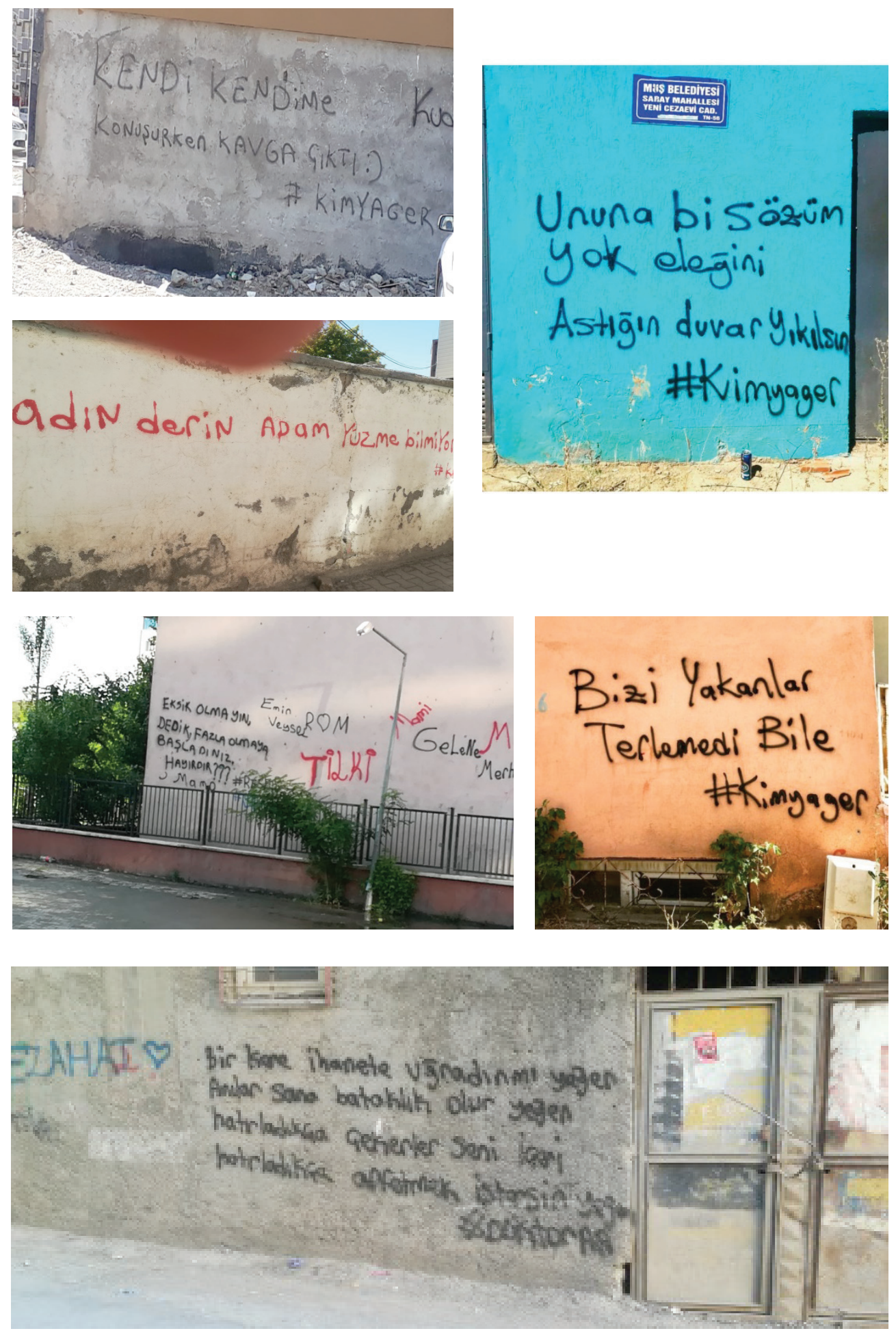

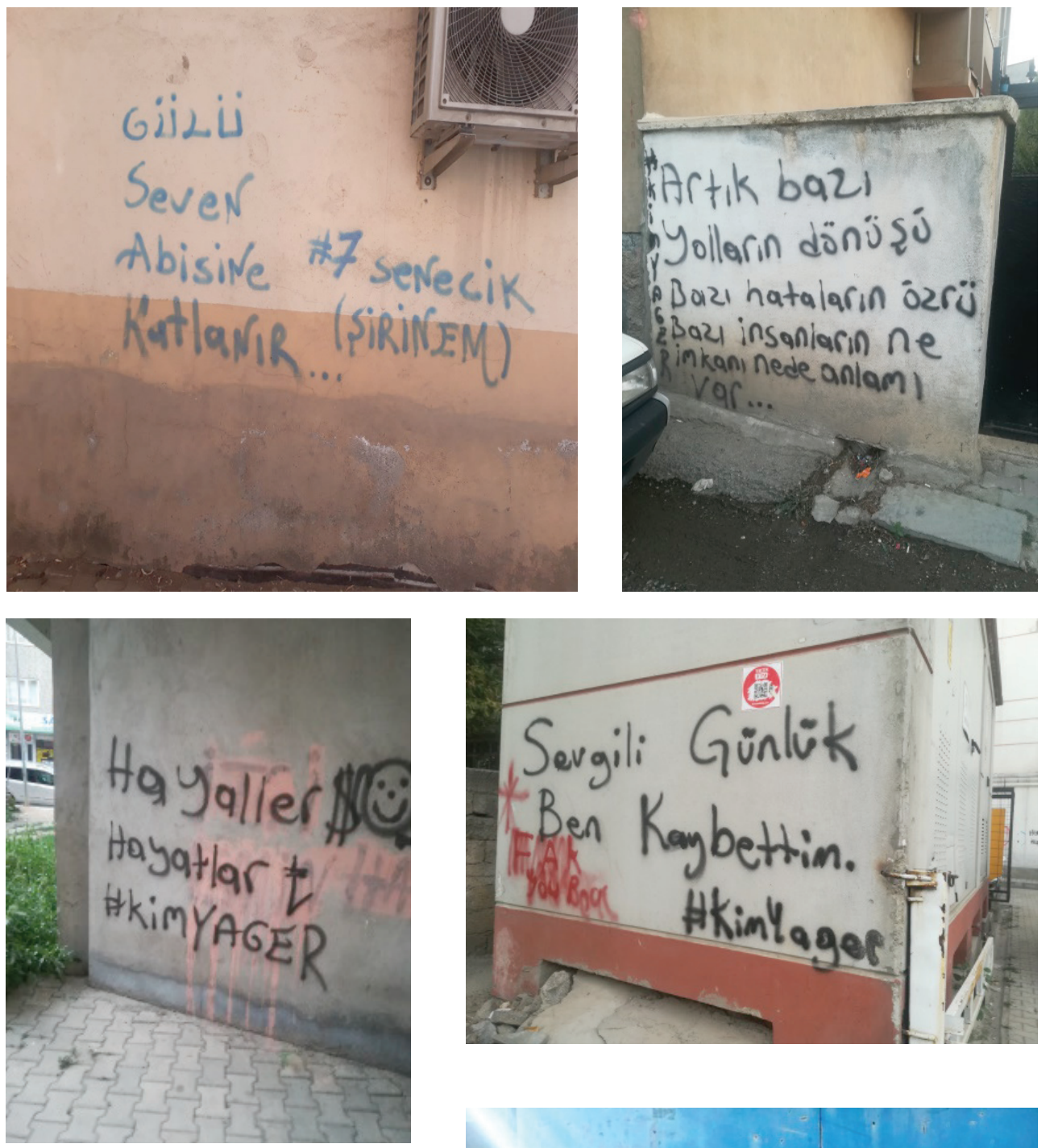

Eksik kaldiginda Beni hatirla
Himeger
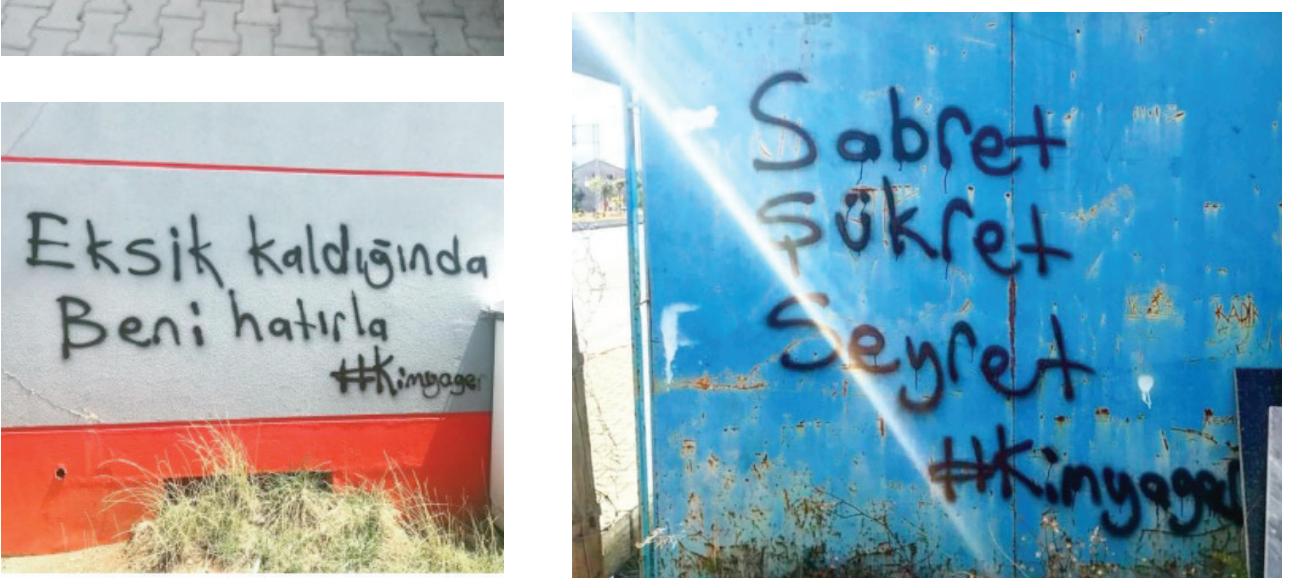